\title{
Promoting and Generating Children's Interest in Reading: Pre-school Stage
}

\author{
Ramziya Mardashova ${ }^{1 *}$, Tatyana Garnysheva ${ }^{1}$, Leila Rakhmatullina $^{1}$, Lilia Sadykova ${ }^{1}$, \\ Firyuza Hazratova $^{2}$, and Ramziya Haertdinova ${ }^{1}$ \\ ${ }^{1}$ Department of Psychological, Pedagogical and Special Defectological Education, Naberezhnye \\ Chelny State Pedagogical University, Naberezhnye Chelny, Russia
}

\begin{abstract}
The article considers and proves the importance of promoting and generating children's interest in reading under current conditions. Generating interest in reading in pre-school children is presented as a specially organized process that determines the world-view development and moral formation of the child's personality at the stage of pre-school childhood. The authors of the article theoretically and experimentally confirm the effectiveness of the forms and methods used when generating pre-schoolers' interest in reading, which meet their age and individual characteristics. The integrative approach used in the educational process helps to improve the content of the work when gaining the objective generating pre-schoolers' interest in reading. The forms and methods applied in the experiment have proved to be effective when generating children's interest in reading and therefore, they can be successfully employed in pre-school education organizations.
\end{abstract}

\section{Introduction}

The cultural decline as well as spiritual and moral decline is the reality of the Russian community over the past few decades. And there are a great number of reasons for this tendency. Without touching on all of them, we will focus on the reason that, in our opinion, involves developing the cultural crisis in Russia.

The changes taking place in the socio-cultural sphere in Russia that is characterized by a relatively low level of general cultural competence and general education of people are mainly due to the rapid loss of interest in reading throughout different social and age groups of the population.

Losing interest in reading is an obvious fact. According to the data provided by "NOP World", one of the ten leading companies that research the book market, the Russians have ceased to be the most reading nation, falling behind the Indians, Chinese, Thais, Filipinos, Egyptians, etc. [1]. The National Program for Reading Promotion and Development describes this situation in Russia as a system crisis in reading culture [2]. Today, Russia is close to the critical limit on reading neglect that may result in a low level of literacy, cultural competence, and opportunities for socio-cultural adaptation.

\footnotetext{
* Corresponding author: Mardashova62@mail.ru
} 
The situation is particularly alarming in children's and adolescents' reading, and the main reason for this situation is lack of interest in reading a book and the need for it. Engaging young people in reading has become far from easy. Reading promotion should start at a young age. Moreover, it is better to start doing it at the pre-school stage as this work involves thoughtful, consistent, purposeful, and specially organised pedagogical activity with pre-schoolers.

The importance of the study is determined by understanding the need to promote and develop reading in children, which is an important element of culture, a factor of developing intellectual potential, creative and social activity of a personality; by clarifying the content of the concepts of "interest", "interest in reading"; by theoretical and experimental proving the effectiveness of the rational forms and methods used when generating children's interest in reading in a pre-school education organization.

The analysis of the scientific literature shows that the issues of organizing children's reading that is a complex creative activity are covered in the works written by L.S. Vygotsky [3], D.B. Elkonin [4], O.I. Nikiforova [5], L.P. Bratukhina [6], O.V. Dzhezheley [7], V.A. Krutetsky [8], E.I. Kuzmenkova [9], M.P. Voyushina [10], etc. A number of issues related to generating the interest in reading in senior pre-school children and their solutions are discussed in the works written by of A.T. Alekseevskaya [11], L.I. Afanasyeva [12], S. Pozdeyeva [13], N.N. Svetlovskaya [14], etc.

The presented study is based on the conceptions of the mechanisms of generating children's interest in activity (L.S. Vygotsky [3], A.I. Leontyev [15], S.L. Rubinshtein [16], L.I. Bozhovich [17], etc.), the importance of interest in the framework of interiorization of the cultural and historical experience in the course of personality development (D.B. Elkonin [4], V.N. Myasishchev [18], G.I. Shchukina [19], etc.).

Taking into account the importance of the issues raised, the study aims at: theoretical and experimental proving the effectiveness of the offered forms and methods to generate senior pre-schoolers' interest in reading.

\section{Materials and methods}

The theoretical analysis is based on the empirical material obtained. The experiment was carried out in the Nizhnekamsk-based kindergarten of the combined type № 40, Republic of Tatarstan. The study involved children from four preparatory groups (two experimental groups and two control groups).

The following methods were used to test the hypothesis, achieve the purpose and particular objectives of the study:

- diagnostic techniques developed by the authors to identify the level of interest in reading in senior pre-school children;

- observation;

- pedagogical experiment (stating, formative, and control stages);

- survey of parents;

- individual interviews with parents and educators;

- mathematical processing of the findings.

\section{Results and discussion}

To meet the targets of the study, we should outline the range of significant achievements of a preschool child when reading a smart and kind book: 1) gathering useful information from different fields of knowledge; 2) forming the views and beliefs; 3) developing 
curiosity, willingness to accept new things and participate in sharing the opinions; 5) forming the way of thinking, developing speech; 6) getting to know the masterpieces of literature.

The study uses the key concepts: "interest", "interest in reading”. Let us define them.

Interest is a form of demonstrating a cognitive need that ensures the individual's orientation to realizing the goal of the activity and thereby promotes learning the new facts as well as a more complete and deeper reflection of the reality [2].

Satisfying the interest does not involve its losing. Conversely, it arouses new interests that meet a higher level of cognitive activity. Interest in the dynamic development can result in tendency to meet the need to be engaged in the activity that arouses interest.

Taking into account the nature of interest as a mental phenomenon, we give a working definition of the concept of "interest in reading".

Interest in reading is a more or less stable emotional cognitive attitude of a reader to books, which is demonstrated through selecting, perceiving and evaluating these books [6].

The crisis in reading is that children have lost interest in this area of study rather than they have stopped reading. Thus, arousing and holding interest is what a teacher uses as a target.

Psychology considers interest to be "the real reason for conscious actions" [5]. For an adult, the reason for conscious actions to read a book can be the need for gathering some information, their own developing, killing time, etc. In pre-school children, interest makes them constantly refer to the same book and think over its content, create games based on the plot of the book, identify themselves with the literary heroes [11].

Interest in reading depends on the age and it is demonstrated through selecting the genre of literature (children of early and young age prefer poetry; pre-schoolers prefer fairytales).

In our opinion, the problem under discussion is very serious. Generating the interest in reading is of great importance when developing a pre-schooler's personality. We have conducted a special study proving that specially selected forms and methods of instructing 6-7-year-old children help to achieve positive outcomes.

First, we studied the level of children's interest in reading. The criteria were as follows: 1) showing interest in the content of a book; 2) selective attitude to the subject or genre of a book; 3) showing interest in the illustrations of a book and correlating them with the content; 4) showing willingness to share impressions about a book or to act out its plot. The indicators for three levels of interest (high, medium, and low) were developed along with those criteria.

After the appropriate diagnostic work had been done, we handled the results and obtained the following data: the experimental group comprised $15 \%$ of the children with a high level of interest in reading, while the control one $-9 \%$; the experimental group comprised $53 \%$ of the children with a medium level, while the control one $-61 \%$ and the experimental group comprised $32 \%$ of the children with a low level, while the control one $30 \%$.

The observation and interviews with the participants of the experiment showed that the children with a low level of interest in reading did not express willingness to read a new book, displayed indifference to discuss the content of the book or answer the questions about the plot, simplified the characteristics and descriptions, and found it difficult to understand causal relationships or the motives of heroes. In addition, they were unable to enjoy the expressive literary language. When retelling the story, they relied on the questions that were asked by the teacher or on the illustrations from the book. The children with a medium level of interest rarely expressed willingness to participate in reading and discussing the book; they retold the book with the teacher's or other children's help. 
However, they willingly looked over the illustrations, took part in the games based on the plot of the book. The children of that level comprised the majority.

The experiment showed that there was a need for organizing special work with the children, which was aimed at generating higher interest in reading. We developed a longterm plan of activities that covered the academic year. The plan included various ways of organizing educational activities in the pre-school organization and in the families (reading, storytelling, retelling, direct instructional activity (DIA), conversations, discussion, situational conversation, modeling, role and didactic games, real-life and game situations, entertainment, holidays, excursions, quizzes, and manual labor). When applying those methods of instruction, the following forms of its organization were used: frontal, individual, and subgroup [Table 1].

Table 1. Sample of Long-term Plan for Generating Interest in Reading (October).

\begin{tabular}{|c|c|c|}
\hline Activity Content & $\begin{array}{l}\text { Interaction with } \\
\text { Other Activities }\end{array}$ & Interaction with Parents \\
\hline $\begin{array}{l}\text { Conversation with children "What do We } \\
\text { Need Books for?" } \\
\text { 1. Addressing questions to children } \\
\text { 2. Putting on exhibition of children's books } \\
\text { 3. Looking over illustrations } \\
\text { 4. Reading a poem by S. Mikhalkov "How } \\
\text { Would we Live without Books" }\end{array}$ & $\begin{array}{l}\text { 1. Manual labor (book } \\
\text { repairing) } \\
\text { 2. Reading a poem by } \\
\text { S. Mikhalkov" } \\
\text { Cripples in the } \\
\text { Library" }\end{array}$ & $\begin{array}{c}\text { Survey of parents } \\
\text { "Importance of Books in } \\
\text { Children Education" }\end{array}$ \\
\hline $\begin{array}{l}\text { Conversation "The Birth of a Book" } \\
\text { 1. Talking about how and by whom books } \\
\text { are created } \\
\text { 2. Addressing questions to children } \\
\text { 3. Putting on exhibition of children's books } \\
\text { 4. Looking over illustrations }\end{array}$ & $\begin{array}{l}\text { 1. Role-playing } \\
\text { "Typography" }\end{array}$ & $\begin{array}{c}\text { Joint } \\
\text { manual labor "Making } \\
\text { Bookmarks" }\end{array}$ \\
\hline $\begin{array}{c}\text { Excursion to library } \\
\text { 1. Talking about books } \\
\text { 2. Observing the librarian's work } \\
\text { 3. Reading poems "Book Land" (Nastya } \\
\text { Valuyeva), "Librarian" (R. Mukha and V. } \\
\text { Levin) }\end{array}$ & $\begin{array}{l}\text { 1.DIA (appliqué) } \\
\text { "Bookmarks" } \\
\text { 2. Role-playing } \\
\text { "Library" }\end{array}$ & Enrolling in the library \\
\hline $\begin{array}{l}\text { Conversation "The Book as the Best Friend } \\
\text { and Teacher" } \\
\text { 1. Summarizing the information received } \\
\text { 2. Putting on exhibition of children's books } \\
\text { 3. Reading a poem by S. Mikhalkov "We are } \\
\text { Friendly with the Printed Word" }\end{array}$ & $\begin{array}{l}\text { 1. Role-playing } \\
\text { "Bookshop" } \\
\text { 2. Designing } \\
\text { "Creating our Own } \\
\text { Book" }\end{array}$ & $\begin{array}{l}\text { Report on "Importance of a } \\
\text { Book in Education" at a } \\
\text { parent-teacher meeting } \\
\text { Exhibition of children's } \\
\text { hand-made books }\end{array}$ \\
\hline
\end{tabular}

As can be seen from the sample of the plan, the children instruction was conducted according to the chosen topic. The topic was determined for each week. For example, October included the following topics: the importance of a book in a person's life; the information about book writing and printing; an excursion to a school and visiting the school library, etc.

We outlined the following tasks to arouse interest in reading:

1. Each teacher should master the art of reading and storytelling.

2. Teach children to perceive a work of art.

3. Teach children to have a good attitude to a book.

The work began with arranging the book corner in the classroom. It was important for us to create such an environment where the children would willingly look over books, learn about their contents. There were not only new books, but also the children's favorite books, or books brought from home, as well as toy books, picture books, panorama books. Some 
more materials were also added to the books: 1) children's drawings, 2) photo albums, 3) sets of postcards; 5) didactic games. We purchased various things for table theatre as well as finger puppets. We selected highly artistic illustrations or pictures (Yu. Vasnetsov, E. Rachev, E. Charushin, V. Suteyev, and A. Barsukov). To act out "Moidodyr", the fairytale written by K.I. Chukovsky, the elements of costumes were made. The design of the front book wall was changed monthly depending on the weekly theme. When selecting books, we were guided by the curriculum standards [2]. The long-term plan included both Russian and Tatar folklore, poetry, and prose (G. Tukai, M. Dzhalil, and A. Alish).

It should be noted that the expressive presentation of a book is important when reading a book and telling a story. Thus, depending on the book we varied the techniques of artistic reading: 1) the specific tone of performance; 2) intonations or shades of voice such as: stress and timbre, tempo and pauses, raising and lowering the voice; 3) facial expressions.

When organizing and conducting instruction, we tried to apply the integrative approach that involved setting and achieving the goal, i.e. to have higher children's interest in reading through three instructional areas: "Artistic and Aesthetic Development", "Cognitive and Speech Development", "Social and Communicative Development". So, in the course of reading the fairytale under the title "The Hare-Boaster", the teacher involved the children in DIA - making a hare model from plasticine; drawing a bear and its cubs when reading "Bear and its Cubs" written by E.I. Charushin; making invitation cards for a performance when preparing to dramatize "New Year Fairytale", and making bookmarks when learning manual labor and appliqué.

The didactic games and situations were widely used in our work ("First and Then", "Magic Box" based on the fairytale "Fox and Grey Wolf", "Solve the Puzzle", "Complete the Verse" (based on the poems written by S. Marshak, etc.).

The children took an interest in the role-plays such as "Typography", "Library", "Bookshop", etc. Along with the role-plays, there were dramatizations based on "Moidodyr" and "The Alive Hat" written by K. Chukovsky and N. Nosov.

The instructors in music and physical culture took part in organizing and giving the quiz based on the fairytales written by K. Chukovsky. They selected the musical compositions and made up the games that helped the children to emotionally perceive the texts and create a friendly atmosphere in the classroom.

Teaching the children to have a good attitude to a book was the focus of attention. For this purpose, the school visit was planned and the children went on an excursion to its library. When attending the class in Extracurricular Reading, the children paid attention how carefully the teacher treated books. After the class, the teacher explained to the children what a book consisted of (the cover, the pages, etc.), how to properly open a book and turn the pages, how to take care of it. The teacher drew the children's attention to the fact that if a book was torn, it was difficult to read it and it could not tell anything. The children visited the school library and learnt about the profession of a librarian. Later they attended a class in Manual Labor. The children independently glued the pages, repaired the books, etc. Their mothers took part in that class and helped the children if it was necessary. During the class the teacher read "Cripples in the Library", the poem written by S. Mikhalkov.

One of the most important aspects of our work was interacting with the children's parents. The applied forms of interacting with parents were as follows: conducting a survey of the parents; holding consultations; making a report at a parent-teacher meeting; organizing joint activities of the parents and the children when making the costumes and dramatizing K. Chukovsky's "Moidodyr"; repairing books; providing joint entertainment, holidays, and quizzes; helping the parents with excursions, etc.. After the excursion to the school library where the children carefully looked over the bookshelves, asked questions, 
we had a conversation with the parents and asked them to enroll their children in the local children's library.

In our opinion, the study aimed at promoting and developing reading in children was fruitful. This is proved by the results of the survey of children obtained after implementing all the planned organizational and pedagogical activities. At the control stage of our experiment the same criteria and indicators as at the beginning of the experiment were applied. The data obtained show that in the experimental group the percentage of children with a low level of interest in reading decreased from $32 \%$ to $10 \%$, the percentage of children with an average level increased by $12 \%$, the percentage of children with a high level increased by $15 \%$. In the control group, the changes were insignificant.

\section{Conclusion}

The findings of our study are as follows:

1. The study has found that children's interest in reading as the key factor in their moral and intellectual development is of great importance.

2. The underlying assumption that generating the interest in reading in pre-school children is effective under certain conditions has been confirmed by the experiment conducted. These conditions are: applying the various forms and methods of work with preschoolers, which meet their age and individual characteristics; employing the integrative approach to educating and instructing; interacting between the stakeholders involved in children instruction.

3. Instruction aimed at creating children's needs for knowledge and development, and in this regard, for interest in reading requires a lot of effort on the part of teachers both within a pre-school education organization and beyond it when interacting with children's families.

4. The problem raised provides a basis for continuing the pedagogical activity in this area, covering all the age stages of early and pre-school childhood.

\section{References}

1. National Program for Reading Support and Development, Moscow, Biblioteka, 1, 2530 (2006).

2. L.A. Karpenko (comp.), Brief Psychology Dictionary, Moscow, Politizdat (1985).

3. L.S. Vygotsky, Personality Psychology, Moscow, Prosveshcheniye (2008).

4. D.B. Elkonin, How to Teach Children to Read, Moscow, Znaniye (1986).

5. O.I. Nikiforova, Psychology of Perceiving Fiction Literature, Moscow, Akademiya (2002).

6. L.P. Bratukhina, Generating Younger Schoolchildren's Interest in Reading, Moscow, Vlados (2012).

7. O.V. Dzhezheley, Getting Ready for Extracurricular Reading Lessons, Moscow, Sfera (2007).

8. V.A. Krutetsky, On Children's Literature and Children's Reading, Moscow, Sfera (2004).

9. E.I. Kuzmenkova, Future Reader Education, Moscow, Prosveshcheniye (2005).

10. M.P. Voyushina, Relevant Challenges to Reading Development, Doshkolnoye Vospitaniye, 6, 18-22 (2011). 
11. A.T. Alekseyevskaya, Generating Reader's Interest in Pre-school Children, Moscow, Akademiya (2008).

12. L.I. Afanasyeva, Generating Interest in Reading in Pre-school Children, Doshkolnoye Vospitaniye, 2, 72-78 (2007).

13. S. Pozdeyeva, On the Issue of Teaching Primary Reading to Senior Pre-schoolers, Doshkolnoye Vospitaniye, 5, 14-18 (2009).

14. N.N. Svetlovskaya, Teaching Reading and Laws of Reader Formation, Nachalnaya Shkola, 1, 11-18 (2003).

15. A.N. Leontyev, Activity. Consciousness. Personality, Moscow, Politizdat, (1975).

16. S.L. Rubinshtein Fundamentals of General Psychology, Moscow, Uchpedgiz (1946).

17. L.I. Bozhovich, Personality and its Formation in Childhood, Moscow, Prosveshcheniye (1968).

18. Myasishchev, V.N. On the Need as a Human Attitude, Moscow, Uchyonyye Zapiski MGU (1956).

19. G.I. Shchukina, Issue of Cognitive Interest in Pedagogy, Moscow, Pedagogika (1971). 